\title{
DIAMOND CORE DRILL FITTINGS
}

\author{
(Fourth Edition)
}

\section{COMMERCIAL STANDARD CS17-47}

(Supersedes CS17-42)

Effective Date for New Production from July 1, 1947

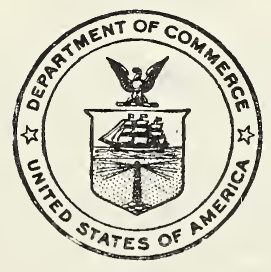

\section{A RECORDED VOLUNTARY STANDARD}

OF THE TRADE

UNITED STATES DEPARTMENT OF COMMERCE

W. AVERELL HARRIMAN, Secretary 


\section{COMMERCIAL STANDARDS}

Commercial Standards are voluntary standards of the trade developed through concerted action of those directly concerned, and issued by the United States Department of Commerce upon written evidence of their acceptability to the trade. They are initiated by written request from a responsible element of business to the Division of Trade Standards of the National Bureau of Standards. The Division of Trade Standards acts as a coordinating and fact-finding agency in ascertaining the desires of all concerned.

The Federal Government exercises no regulatory authority in the enforcement of Commercial Standards. In accepting a Commercial Standard, the producer, distributor, or user says in effect that he considers it a useful standard of practice, and plans to utilize it as far as practicable in his business, reserving the right to depart from the standard so long as no deception results from such departure. When reference to a Commercial Standard is made in contracts, labels, invoices, or advertising literature, however, the provisions of the standard are enforcible through usual legal channels as a part of the sales contract.

Organized in 1927 , the Division of Trade Standards has assisted many industries in the development of Commercial Standards for a wide variety of commodities. A list of previously established Commercial Standards appears herein.

\section{COMMERCIAL STANDARD FOR DIAMOND CORE DRILL FITTINGS}

On May 27, I929, at the instance of the Diamond Core Drill Manufacturers Association, a joint conference of representative manufacturers, drilling contractors and general interests adopted a commercial standard for diamond core drill fitting which was accepted by the industry and published as Commercial Standard CSI7-30. In I932, upon recommendation of the standing committee to keep abreast of progress, a revision was adopted and issued as CSI 7-32. Subsequently, a proposal of the Diamond Core Drill Manufacturers Association, to extend the scope of the standard was adopted and issued as CSI7-42. This revision, due to war conditions, was not put in to effect.

Pending completion of developments toward further revision, the Diamond Core Drill Manufacturers Association recommended that the requirements of the 1932 edition be made available in current commercial standards form. Accordingly, upon endorsement by the standing committee, a draft so prepared was circulated on November 2I, I946 for acceptance. Those concerned have since accepted and approved the revised standard as shown herein.

Project Manager:

F. E. Powell, assisted by W. H. Jackett, JR., Division of Trade Standards, National Bureau of Standards,

Technical Adviser:

D. R. MrLler, Division of Metrology, National Bureau of Standards. 
for

\section{DIAMOND CORE DRILL FITTINGS}

\section{(Fourth Edition)}

\section{PURPOSE}

1. The purpose of this commercial standard is to provide dimensional interchangeability in essential diamond core drill fittings as made by American manufacturers. The difficulty of replacing parts in the field should therefore be minimized, since sizes and size designations are identical for all manufacturers.

\section{SCOPE}

2. This standard covers standard designs and tolerances with controlling dimensions for rod couplings, drill rods, core-barrel bits, casing couplings, casings, and casing bits. Dimensions of core-barrel bits apply to these items as machine-shop products prior to being set with drilling diamonds.

\section{GENERAL}

3. The following nomenclature, symbols, dimensions, tolerances, and types are recommended as standard for diamond core drill fittings.

4. The four sizes of diamond core drill casing shall be known as $\mathrm{EX}, \mathrm{AX}, \mathrm{BX}$, and NX. The corresponding sizes of bits, core barrels, and casing couplings shall be known as $\mathrm{EX}, \mathrm{AX}, \mathrm{BX}$, and NX. Rod and rod coupling sizes are known as $\mathrm{E}, \mathrm{A}, \mathrm{B}$, and $\mathrm{N}$. Nominal dimensions are given in table 1 and illustrated in figure 1.

TABLE 1.-Nominal dimensions

\begin{tabular}{|c|c|c|c|c|c|c|c|c|c|}
\hline \multicolumn{2}{|c|}{ Size designation } & \multirow{2}{*}{$\begin{array}{l}\text { Casing } \\
\text { O.D. }\end{array}$} & \multicolumn{2}{|c|}{ Casing coupling } & \multirow{2}{*}{$\begin{array}{l}\text { Casing } \\
\text { bit O.D. }\end{array}$} & \multirow{2}{*}{$\begin{array}{c}\text { Core- } \\
\text { barrel } \\
\text { bit O.D. }\end{array}$} & \multirow{2}{*}{$\begin{array}{l}\text { Drill } \\
\text { rod O.D. }\end{array}$} & \multirow{2}{*}{$\begin{array}{c}\text { Diam- } \\
\text { eter } \\
\text { of hole } \\
\text { made by } \\
\text { core- } \\
\text { barrel } \\
\text { bit }^{1}\end{array}$} & \multirow{2}{*}{$\begin{array}{l}\text { Approxi- } \\
\text { mate } \\
\text { diam- } \\
\text { eter } \\
\text { of core }\end{array}$} \\
\hline 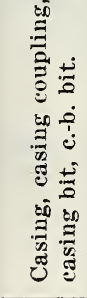 & 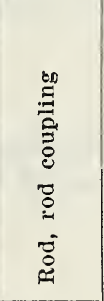 & & O.D. & I.D. & & & & & \\
\hline $\begin{array}{l}\mathbf{E X} \\
\mathbf{A X}- \\
\mathbf{B X} \\
\mathbf{N X}_{-}\end{array}$ & $\begin{array}{l}\mathbf{E}_{---} \\
\mathbf{A}_{-} \\
\mathbf{B}_{---} \\
\mathbf{N}_{---}\end{array}$ & \begin{tabular}{ll}
\multicolumn{1}{c}{ in. } \\
1 & $13 / 16$ \\
2 & $1 / 4$ \\
2 & $7 / 8$ \\
3 & $1 / 2$
\end{tabular} & \begin{tabular}{ll}
\multicolumn{2}{c}{ in. } \\
1 & $13 / 16$ \\
2 & $1 / 4$ \\
2 & $7 / 8$ \\
3 & $1 / 2$
\end{tabular} & \begin{tabular}{cc}
\multicolumn{1}{c}{ in. } \\
1 & $1 / 2$ \\
1 & $29 / 32$ \\
2 & $3 / 8$ \\
3 &
\end{tabular} & \begin{tabular}{lr}
\multicolumn{1}{c}{$i n}$. \\
1 & $27 / 32$ \\
2 & $5 / 16$ \\
2 & $15 / 16$ \\
3 & $9 / 16$
\end{tabular} & \begin{tabular}{rr}
\multicolumn{2}{c}{$i n}$. \\
1 & $7 / 16$ \\
1 & $27 / 32$ \\
2 & $5 / 16$ \\
2 & $15 / 16$
\end{tabular} & $\begin{array}{cc} & \text { in. } \\
1 & 5 / 16 \\
1 & 5 / 8 \\
1 & 29 / 32 \\
2 & 3 / 8\end{array}$ & $\begin{array}{ll}\text { in. } \\
1 & 1 / 2 \\
1 & 7 / 8 \\
2 & 3 / 8 \\
3 & \end{array}$ & $\begin{array}{ll}\text { in. } & \\
& 7 / 8 \\
1 & 1 / 8 \\
1 & 5 / 8 \\
2 & 1 / 8\end{array}$ \\
\hline
\end{tabular}

${ }^{1}$ Assuming hole $1 / 32 \mathrm{in.}$ larger than bit and listing diameters to nearest $1 / 8 \mathrm{in}$. 
5. Casings made flush on the outside when connected with couplings shall be known as "flush-coupled casing"; when connected without couplings, shall be known as "flush-joint casing." The threads of both are identical.

6. Core barrels shall be known as "single-tube core barrels," "rigidtype double-tube core barrels," or "swivel-type double-tube core barrels," as the case may be.

7. Single-tube and double-tube core-barrel bits shall be identical as regards the outside diameter and thread.

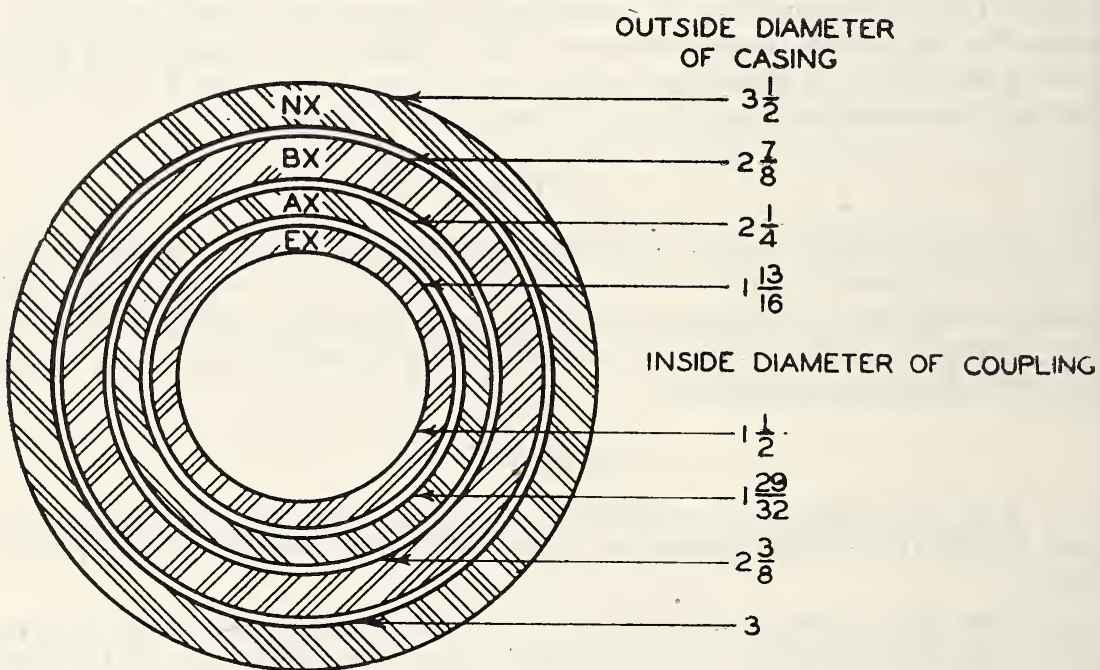

Figure 1.-Section through casing couplings.

8. The term "reaming shell" shall be used in preference to "swell coupling." The bit thread of reaming shells and core shells shall conform to the standard bit thread.

9. The approximate sizes of standard cores are: $\mathrm{EX}, 7 / 8$ inch; $\mathbf{A X}$, $11 / 8$ in.; BX, 15/8 in.; NX, $21 / 8$ in. Larger cores are obtainable with special fittings.

\section{DETAIL REQUIREMENTS}

10. The dimensions and tolerances for drill rod couplings, drill rods, core-barrel bits, casing couplings, casings, and casing bits are given in tables 2 to 7 , inelusive. 
Diamond Core Drill Fittings

TARLe 2.-Drill rod couplings
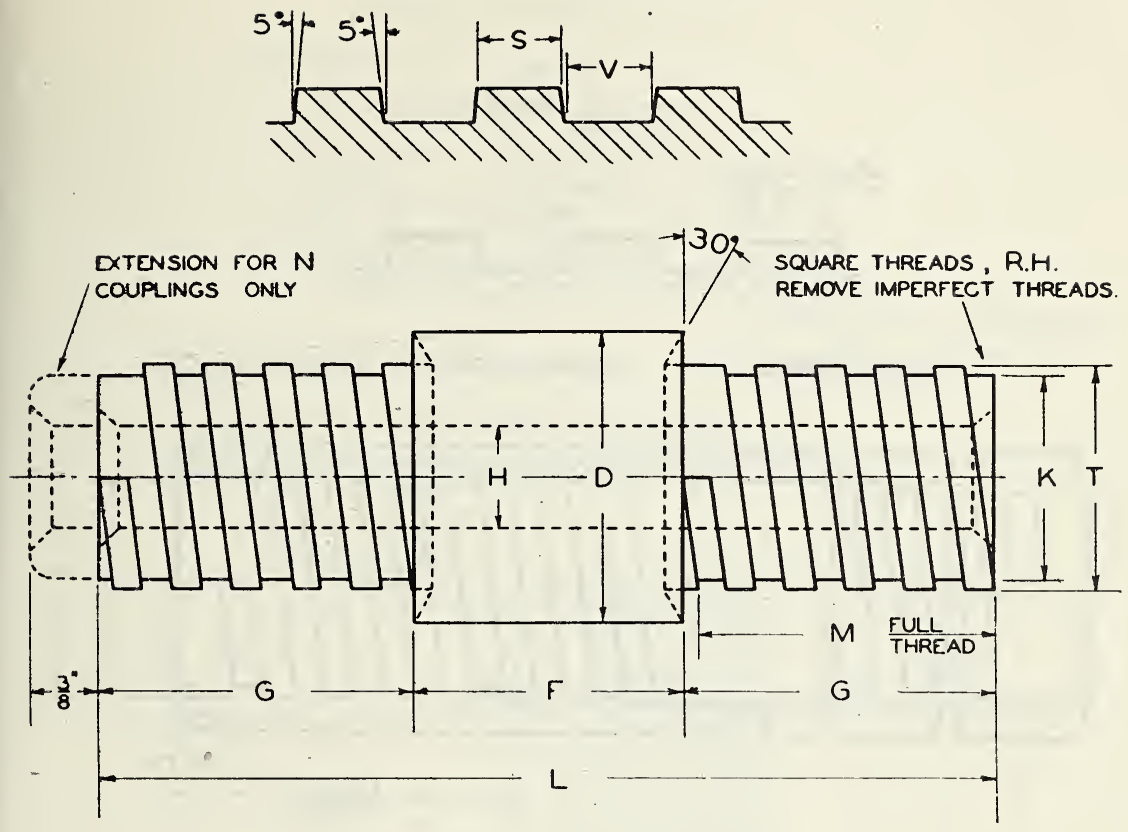

\begin{tabular}{|c|c|c|c|c|c|c|c|c|}
\hline \multirow{2}{*}{\multicolumn{2}{|c|}{$\begin{array}{c}\text { Designating } \\
\text { symbol }\end{array}$}} & \multirow{2}{*}{ D } & \multirow{2}{*}{$\mathbf{F}$} & \multirow{2}{*}{ G } & \multirow{2}{*}{$H$} & \multirow{2}{*}{$\begin{array}{l}\text { Threads } \\
\text { per } \\
\text { in. }\end{array}$} & \multicolumn{2}{|c|}{$\mathbf{K}$} \\
\hline & & & & & & & Max. & Min. \\
\hline \multicolumn{2}{|c|}{ 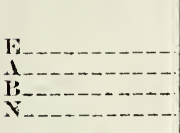 } & $\begin{array}{cc}{ }^{i n .} \\
1 & 5 / 16 \\
1 & 5 / 8 \\
1 & 29 / 32 \\
2 & 3 / 8\end{array}$ & $\begin{array}{ll}i n . \\
1 & 1 / 2 \\
1 & 1 / 2 \\
1 & 1 / 2 \\
1 & 1 / 2\end{array}$ & $\begin{array}{ll}i n . \\
1 & 1 / 2 \\
1 & 3 / 4 \\
1 & 7 / 8 \\
2 & 3 / 8\end{array}$ & $\begin{array}{l}i 11 . \\
7 / 16 \\
9 / 16 \\
5 / 8 \\
1^{5 / 8}\end{array}$ & $\begin{array}{l}3 \\
3 \\
3 \\
5 \\
4\end{array}$ & $\begin{array}{l}i n . \\
0.874 \\
1.139 \\
1.280 \\
1.686\end{array}$ & $\begin{array}{l}\text { in. } \\
0.870 \\
1.134 \\
1.275 \\
1.681\end{array}$ \\
\hline \multirow{2}{*}{$\begin{array}{l}\text { Desig- } \\
\text { nating } \\
\text { symbol }\end{array}$} & \multirow{2}{*}{$\mathbf{L}$} & \multirow{2}{*}{ II } & \multicolumn{2}{|c|}{$s$} & \multicolumn{2}{|r|}{$\mathbf{T}$} & \multicolumn{2}{|c|}{ V } \\
\hline & & & Max. & Min. & Max. & Min. & $\operatorname{Max}$. & Min. \\
\hline $\begin{array}{l}\mathrm{F} \\
\mathrm{A} \\
\mathrm{P} \\
\mathrm{N}\end{array}$ & $\begin{array}{ll}i n . \\
4 & 1 / 2 \\
5 & \\
5 & 1 / 4 \\
6 & 1 / 4\end{array}$ & $\begin{array}{rr}i n . \\
1 & 7 / 16 \\
1 & 11 / 16 \\
1 & 13 / 16 \\
2 & 5 / 16\end{array}$ & $\begin{array}{l}\text { in. } \\
0.1608 \\
.1608 \\
.0941 \\
.1164\end{array}$ & $\begin{array}{l}\text { in. } \\
0.1563 \\
.1563 \\
.0897 \\
.1120\end{array}$ & $\begin{array}{l}i n . \\
0.999 \\
1.264 \\
1.405 \\
1.874\end{array}$ & $\begin{array}{l}\text { in. } \\
0.998 \\
1.263 \\
1.404 \\
1.873\end{array}$ & $\begin{array}{c}i n . \\
0.1657 \\
.1657 \\
.0990 \\
.1212\end{array}$ & $\begin{array}{l}\text { in. } \\
0.1617 \\
.161 \% \\
.0950 \\
.117:\end{array}$ \\
\hline
\end{tabular}




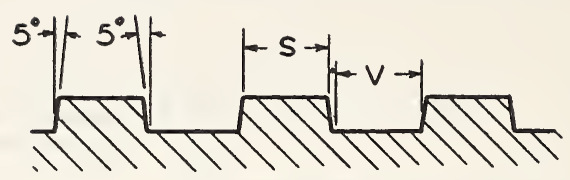

SQUARE THREAD, R.H. REMOVE IMPERFECT THREADS. J $30^{\circ}$ F

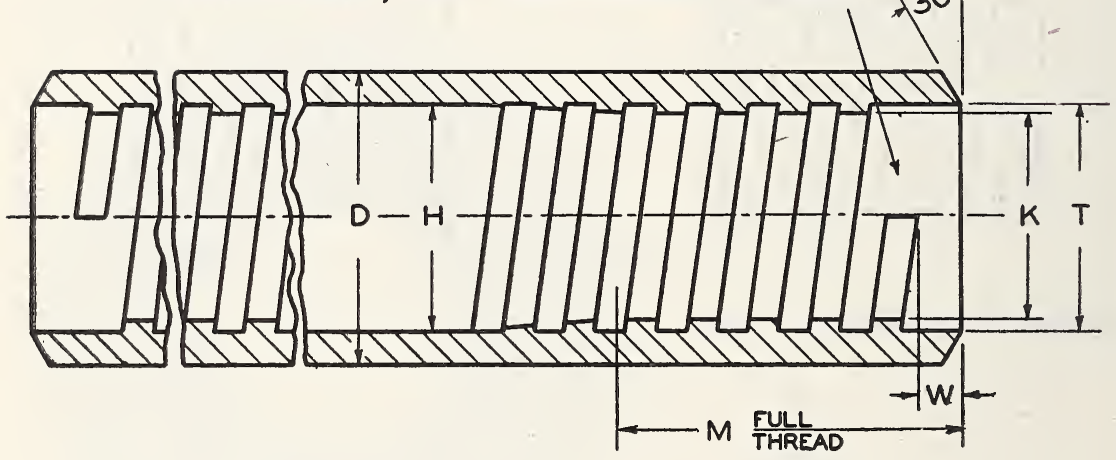

\begin{tabular}{|c|c|c|c|c|c|c|c|c|c|c|c|c|c|}
\hline \multirow{2}{*}{ 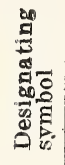 } & \multirow{2}{*}{ D } & \multirow{2}{*}{$\mathrm{H}$} & \multicolumn{2}{|c|}{$\mathrm{K}$} & \multirow{2}{*}{ M } & \multicolumn{2}{|c|}{$\mathrm{S}$} & \multicolumn{2}{|c|}{$\mathrm{T}$} & \multirow{2}{*}{ 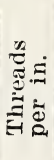 } & \multicolumn{2}{|c|}{ V } & \\
\hline & & & Max. & Min. & & Max. & Min. & Max. & Min. & & Max. & Min. & \\
\hline & \begin{tabular}{cc}
\multicolumn{1}{l}{$i n}$. \\
1 & $5 / 16$ \\
1 & $5 / 8$ \\
1 & $29 / 32$
\end{tabular} & 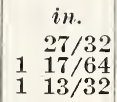 & $\begin{array}{c}\text { in. } \\
0.877 \\
1.142 \\
1.283\end{array}$ & \begin{tabular}{c|}
$i n$. \\
0.876 \\
1.141 \\
1.282
\end{tabular} & $\begin{array}{ll} & \text { in. } \\
1 & 5 / 8 \\
1 & 7 / 8 \\
2 & \end{array}$ & $\begin{array}{c}\text { in. } \\
0.1608 \\
.1608 \\
.0941\end{array}$ & $\begin{array}{c}\text { in. } \\
0.1544 \\
.1544 \\
.0877\end{array}$ & $\begin{array}{c}i n . \\
1.002 \\
1.267 \\
1.408\end{array}$ & $\begin{array}{c}i n . \\
1.001 \\
1.266 \\
1.407\end{array}$ & $\begin{array}{l}3 \\
3 \\
5\end{array}$ & $\begin{array}{c}i n . \\
0.1680 \\
.1680 \\
.1014\end{array}$ & $\begin{array}{c}i n . \\
0.1617 \\
.1617 \\
.0950\end{array}$ & $\begin{array}{l}\text { in. } \\
1 / 4 \\
1 / 4 \\
1 / 4\end{array}$ \\
\hline$N_{-}$ & $\left\{\begin{array}{l}\text { Max. } \\
\text { Min. } 2.385\end{array}\right.$ & 2 & 1.689 & 1.688 & $21 / 2$ & .1163 & .1099 & 1.877 & 1.876 & 4 & .1236 & .1173 & $5 / 16$ \\
\hline
\end{tabular}


TABLE 4.-Core-barrel bits ${ }^{1}$

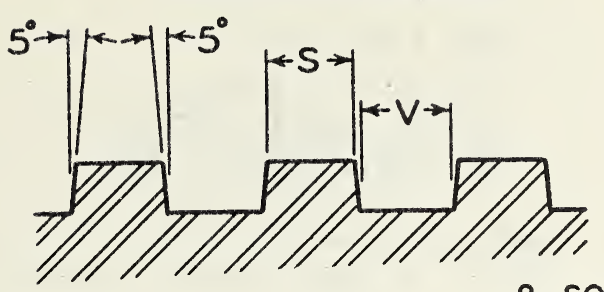

\section{8- SQUARE THREADS PER INCH-R.H.}

\section{ON BEVEL BITS THE INCLUDED} ANGLE OF BEVEL IS TO BE 10 DEGREES

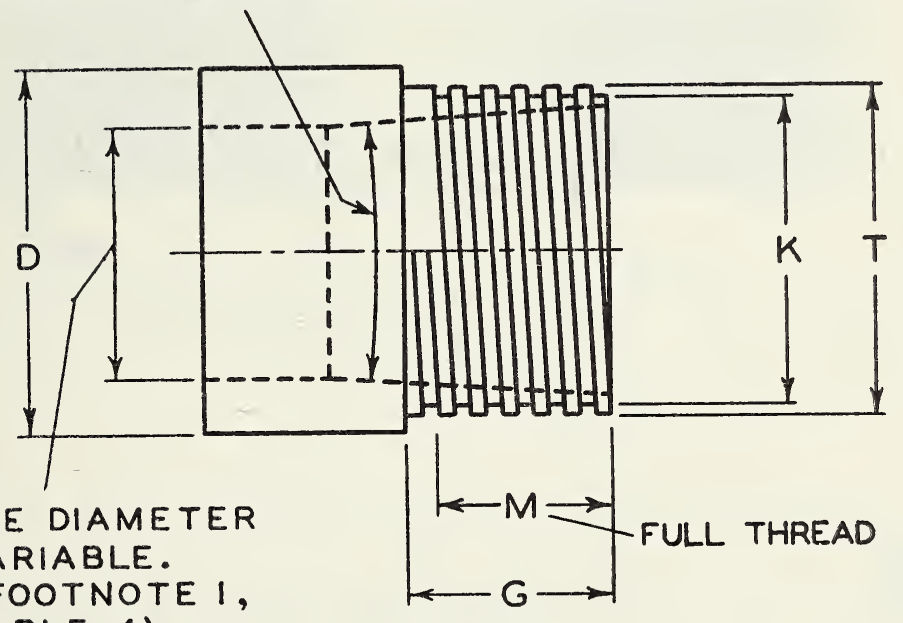

INSIDE DIAMETER VARIABLE. (SEE FOOTNOTE 1, TABLE 4)

\begin{tabular}{|c|c|c|c|c|c|c|c|c|c|c|c|c|}
\hline \multirow{2}{*}{$\begin{array}{c}\text { Desig- } \\
\text { nating } \\
\text { sym- } \\
\text { bol }\end{array}$} & \multicolumn{2}{|c|}{ D } & \multirow{2}{*}{ G } & \multicolumn{2}{|c|}{$\mathrm{K}$} & \multirow{2}{*}{$\mathrm{M}^{2}$} & \multicolumn{2}{|c|}{$S$} & \multicolumn{2}{|c|}{$\mathrm{T}$} & \multicolumn{2}{|c|}{ V } \\
\hline & Max. & Min. & & Max. & Min. & & Max. & Min. & Max. & Min. & Max. & Min. \\
\hline & $i n$. & $i n$ & $i n$. & $i n$. & $i n$. & $i n$. & $i n$. & in. & in. & in. & $i n$. & $i n$. \\
\hline $\mathrm{EX}$ & 1.439 & 1.435 & $7 / 8$ & 1.124 & 1.119 & $3 / 4$ & 0.0594 & 0.0550 & 1.186 & 1.185 & 0.0642 & 0.0602 \\
\hline AX & 1.845 & 1.841 & 1 & 1.499 & 1.494 & $7 / 8$ & .0594 & .0550 & 1.561 & 1.560 & .0642 & .0602 \\
\hline $\mathrm{BX}_{-}$ & 2.314 & 2.310 & $11 / 8$ & 1.967 & 1.962 & & .0594 & .0550 & 2.030 & 2.029 & .0642 & .0602 \\
\hline $\mathrm{NX}_{-}$ & 2.939 & 2.935 & $11 / 4$ & 2.592 & 2.587 & $11 / 8$ & .0594 & .0550 & 2.655 & 2.654 & .0642 & .0602 \\
\hline
\end{tabular}

1 Inside diameters for use in manufacturing and not as a "commercial standard" are as follows: $\mathrm{EX}, 7 / 8(0.877$ to 0.873$)$ in.; $\mathrm{AX}, 1 \mathrm{7/32}(1.220$ to 1.216$)$ in. ; $\mathbf{B X}, 111 / 16$ (1.689 to 1.685$)$ in. ; and $\mathrm{NX}, 23 / 16(2.189$ to 2.185$)$ in.

2 Threads shall be full form to within $1 / 8$ in. of shoulder. 
TABLE 5.-Casing couplings
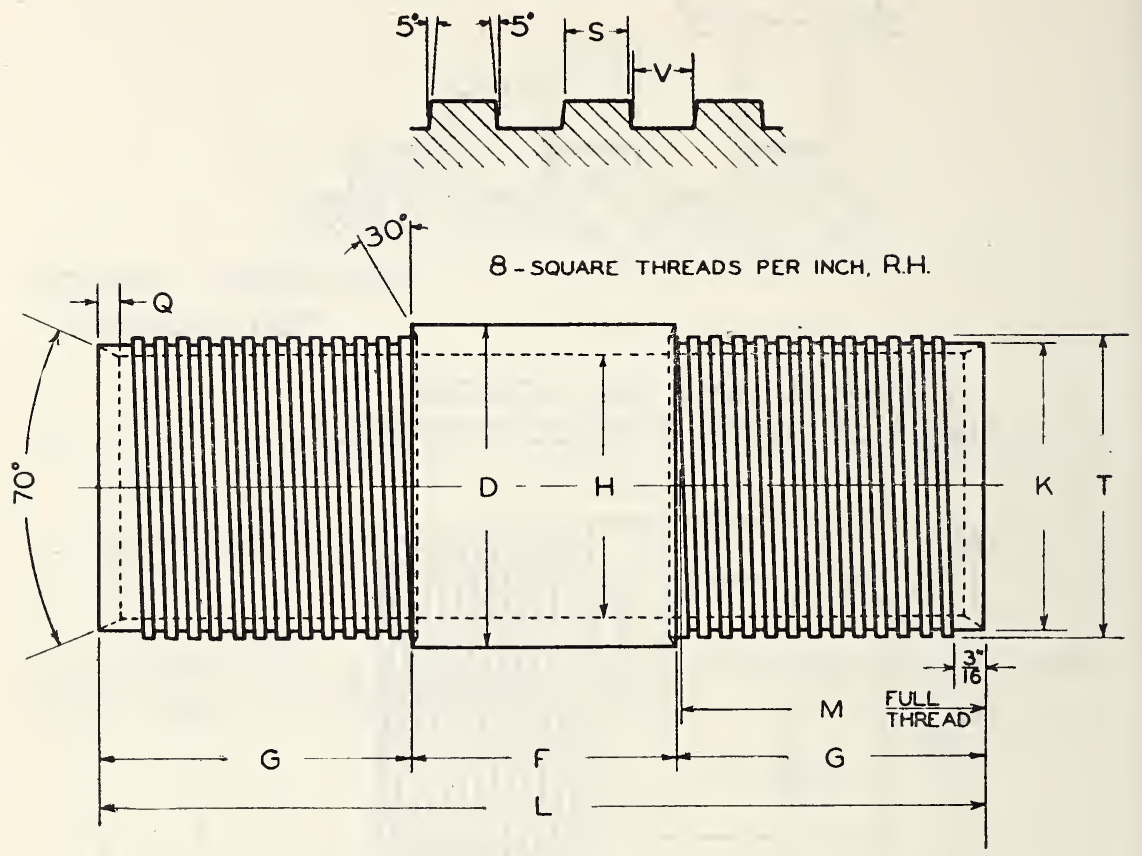

\begin{tabular}{|c|c|c|c|c|c|c|c|c|c|}
\hline \multirow{2}{*}{$\begin{array}{c}\text { Desig- } \\
\text { nating } \\
\text { sym- } \\
\text { bol }\end{array}$} & \multirow{2}{*}{ D } & \multirow{2}{*}{ F } & \multirow{2}{*}{ G } & \multicolumn{2}{|c|}{$\mathrm{H}$} & \multicolumn{2}{|c|}{$\mathrm{K}$} & \multirow{2}{*}{ L } & \multirow{2}{*}{$\mathrm{MH}^{1}$} \\
\hline & & & & Max. & Min. & Max. & Min. & & \\
\hline $\begin{array}{l}\mathrm{EX}- \\
\mathrm{AX}- \\
\mathrm{BX}- \\
\mathrm{NX}\end{array}$ & $\begin{array}{ll} & \text { in. } \\
1 & 13 / 16 \\
2 & 1 / 4 \\
2 & 7 / 8 \\
3 & 1 / 2\end{array}$ & $\begin{array}{ll} & i n . \\
1 & 1 / 2 \\
3 & \\
3 & 1 / 2 \\
3 & 1 / 2\end{array}$ & $\begin{array}{ll} & i n . \\
1 & 3 / 4 \\
2 & \\
2 & 1 / 8 \\
2 & 3 / 8\end{array}$ & $\begin{array}{c}\text { in. } \\
1.502 \\
1.908 \\
2.377 \\
3.002\end{array}$ & $\begin{array}{c}i n . \\
1.498 \\
1.904 \\
2.373 \\
2.998\end{array}$ & $\begin{array}{c}i n . \\
1.655 \\
2.061 \\
2.592 \\
3.217\end{array}$ & $\begin{array}{c}\text { in. } \\
1.650 \\
2.056 \\
2.587 \\
3.212\end{array}$ & $\begin{array}{ll}i n . \\
5 \\
7 & \\
7 & 3 / 4 \\
8 & 1 / 4\end{array}$ & $\begin{array}{ll}i n . \\
1 & 5 / 8 \\
1 & 7 / 8 \\
2 & \\
2 & 1 / 4\end{array}$ \\
\hline
\end{tabular}

\begin{tabular}{|c|c|c|c|c|c|c|c|}
\hline \multirow{2}{*}{$\begin{array}{c}\text { Designating } \\
\text { symbol }\end{array}$} & \multirow{2}{*}{$\mathbf{Q}$} & \multicolumn{2}{|c|}{$\mathrm{S}$} & \multicolumn{2}{|c|}{$\mathbf{T}$} & \multicolumn{2}{|c|}{$\mathbf{V}$} \\
\hline & & Max. & Min. & Max. & Min. & Max. & Min. \\
\hline $\begin{array}{l}\mathrm{EX}- \\
\mathrm{AX} \\
\mathrm{BX} \\
\mathrm{NX}\end{array}$ & \begin{tabular}{l}
\multicolumn{1}{c}{ in. } \\
$1 / 8$ \\
$3 / 16$ \\
$1 / 4$ \\
$1 / 4$
\end{tabular} & $\begin{array}{l}i n . \\
0.0594 \\
.0593 \\
.0580 \\
.0580\end{array}$ & $\begin{array}{l}\text { in. } \\
0.0550 \\
.0549 \\
.0536 \\
.0536\end{array}$ & $\begin{array}{l}\text { in. } \\
1.717 \\
2.124 \\
2.686 \\
3.311\end{array}$ & $\begin{array}{l}\text { in. } \\
1.716 \\
2.123 \\
2.685 \\
3.310\end{array}$ & $\begin{array}{l}\text { in. } \\
0.0642 \\
.0642 \\
.0629 \\
.0629\end{array}$ & $\begin{array}{l}i n . \\
0.0602 \\
.0602 \\
.0588 \\
.0588\end{array}$ \\
\hline
\end{tabular}

${ }^{1}$ Threads shall be full form to within $1 / 8 \mathrm{in}$. of shoulder. 


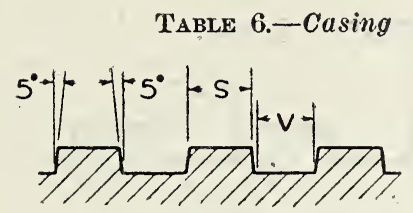

8- SQUARE THREADS PER INCH, RH

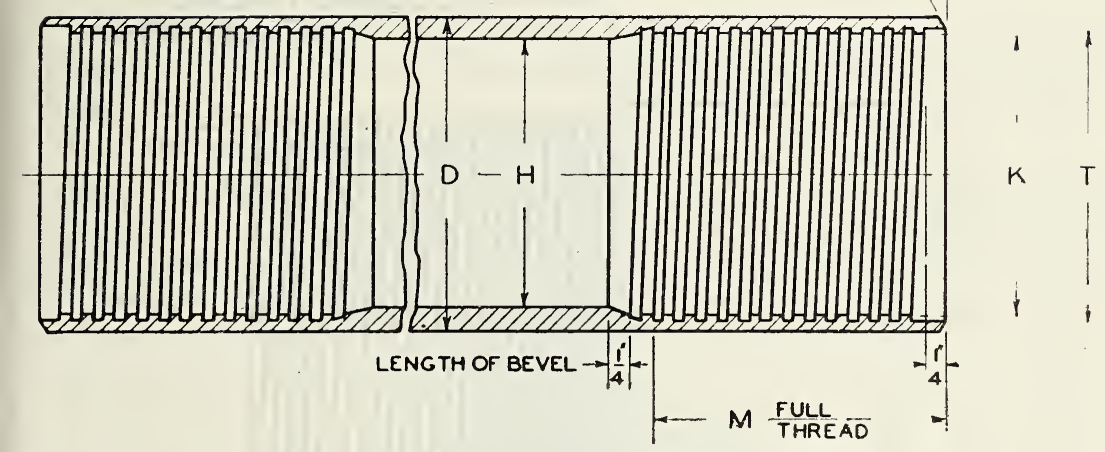

\begin{tabular}{|c|c|c|c|c|c|c|c|c|c|c|c|c|c|}
\hline \multirow{2}{*}{$\begin{array}{c}\text { Desig- } \\
\text { nating } \\
\text { sym- } \\
\text { bol }\end{array}$} & \multirow{2}{*}{\multicolumn{2}{|c|}{ D }} & \multirow{2}{*}{\multicolumn{2}{|c|}{ II }} & \multicolumn{2}{|c|}{$\mathrm{K}$} & \multirow{2}{*}{$\mathbf{M}^{1}$} & \multicolumn{2}{|c|}{$\mathbf{S}$} & \multicolumn{2}{|c|}{$\mathbf{T}$} & \multicolumn{2}{|c|}{$\mathbf{V}$} \\
\hline & & & & & Max. & Min. & & Max. & Min. & Max. & Min. & Max. & Min. \\
\hline $\begin{array}{l}\mathbf{H X} \\
\mathrm{AX} \\
\mathbf{B X} \\
\mathbf{N X}\end{array}$ & $\begin{array}{l}1 \\
2 \\
2 \\
3\end{array}$ & $\begin{array}{l}\text { in. } \\
13 / 16 \\
1 / 4 \\
7 / 8 \\
1 / 2\end{array}$ & $\begin{array}{l}1 \\
2 \\
2 \\
3\end{array}$ & $\begin{array}{l}i n . \\
5 / 8 \\
15 / 32 \\
1 / 16\end{array}$ & $\begin{array}{l}\text { in. } \\
1.658 \\
2.064 \\
2.595 \\
3.220\end{array}$ & $\begin{array}{l}\text { ln. } \\
1.657 \\
2.063 \\
2.594 \\
3.219\end{array}$ & $\begin{array}{ll}\text { in. } \\
1 & 7 / 8 \\
2 & 1 / 8 \\
2 & 1 / 4 \\
2 & 1 / 2\end{array}$ & $\begin{array}{c}i n . \\
0.0593 \\
.0593 \\
.0579 \\
.0579\end{array}$ & $\begin{array}{c}i n . \\
0.0529 \\
.0529 \\
.0515 \\
.0515\end{array}$ & \begin{tabular}{l|} 
in. \\
1.720 \\
2.127 \\
2.689 \\
3.314
\end{tabular} & $\begin{array}{l}i n . \\
1.719 \\
2.126 \\
2.688 \\
3.313\end{array}$ & $\begin{array}{l}\text { in. } \\
0.0667 \\
.0665 \\
.0652 \\
.0652\end{array}$ & $\begin{array}{c}\text { in. } \\
0.0602 \\
.0602 \\
.0589 \\
.0589\end{array}$ \\
\hline
\end{tabular}

1 Threads shall be recessed $1 / 4 \mathrm{in}$. 

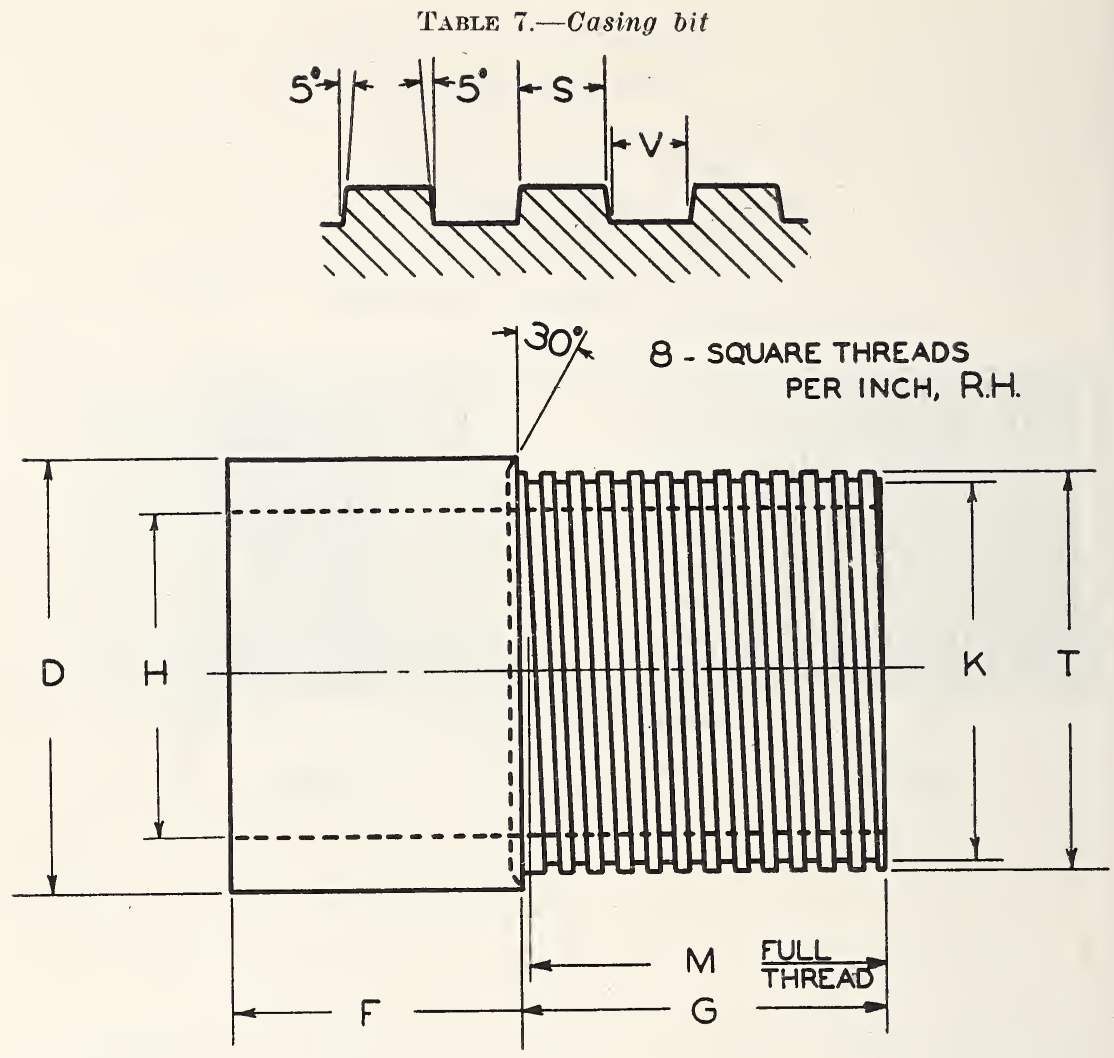

\begin{tabular}{|c|c|c|c|c|c|c|c|}
\hline \multirow{2}{*}{$\begin{array}{l}\text { Designating } \\
\text { symbol }\end{array}$} & \multicolumn{2}{|c|}{ D } & \multirow{2}{*}{$F$} & \multirow{2}{*}{ G } & \multirow{2}{*}{$\begin{array}{c}\mathrm{H} \\
\text { (Approxi- } \\
\text { mate) }\end{array}$} & \multicolumn{2}{|c|}{$\mathbf{K}$} \\
\hline & $\operatorname{Max}$. & Min. & & & & Max. & Min. \\
\hline $\begin{array}{l}\text { EX } \\
\text { AX } \\
\text { BX } \\
\text { NXX }\end{array}$ & $\begin{array}{c}\text { in. } \\
1.845 \\
2.314 \\
2.939 \\
3.564\end{array}$ & $\begin{array}{c}i n . \\
1.841 \\
2.310 \\
2.935 \\
3.560\end{array}$ & $\begin{array}{ll}i n . \\
1 & 1 / 4 \\
1 & 1 / 2 \\
1 & 3 / 4 \\
2 & \end{array}$ & \begin{tabular}{rr}
\multicolumn{2}{c}{ in. } \\
1 & $9 / 16$ \\
1 & $13 / 16$ \\
1 & $15 / 16$ \\
1 & $15 / 16$
\end{tabular} & \begin{tabular}{cc}
\multicolumn{2}{c}{ in. } \\
1 & $7 / 16$ \\
1 & $13 / 16$ \\
2 & $1 / 4$ \\
2 & $7 / 8$
\end{tabular} & $\begin{array}{l}\text { in. } \\
1.655 \\
2.061 \\
2.592 \\
3.217\end{array}$ & $\begin{array}{l}\text { in. } \\
1.650 \\
2.056 \\
2.587 \\
3.212\end{array}$ \\
\hline
\end{tabular}

\begin{tabular}{|c|c|c|c|c|c|c|c|}
\hline \multirow{2}{*}{$\begin{array}{l}\text { Designating } \\
\text { symbol }\end{array}$} & \multirow{2}{*}{$M^{1}$} & \multicolumn{2}{|c|}{$s$} & \multicolumn{2}{|c|}{$\mathrm{T}$} & \multicolumn{2}{|c|}{$V$} \\
\hline & & Max. & Min. & Max. & Min. & $\operatorname{Max}$. & Min. \\
\hline $\begin{array}{l}\mathbf{E X} \\
\mathbf{A X} \\
\mathbf{H X} \\
\mathbf{N X}\end{array}$ & \begin{tabular}{rr}
\multicolumn{2}{c}{ in. } \\
1 & $7 / 16$ \\
1 & $11 / 16$ \\
1 & $13 / 16$ \\
1 & $13 / 16$
\end{tabular} & $\begin{array}{l}\text { in. } \\
0.0594 \\
.0593 \\
.0580 \\
.0580\end{array}$ & $\begin{array}{l}i n . \\
0.0550 \\
.0549 \\
.0536 \\
.0536\end{array}$ & $\begin{array}{l}\text { in. } \\
1.717 \\
2.124 \\
2.686 \\
3.311\end{array}$ & $\begin{array}{l}\text { in. } \\
1.716 \\
2.123 \\
2.685 \\
3.310\end{array}$ & $\begin{array}{l}i n . \\
0.0642 \\
.0642 \\
.0629 \\
.0629\end{array}$ & $\begin{array}{l}i n . \\
0.0602 \\
.0602 \\
.0588 \\
.0588\end{array}$ \\
\hline
\end{tabular}

${ }^{1}$ Threads shall be full form to within $1 / 8$ in. of shoulder. 


\section{Diamond Core Drill Fittings}

\section{IDENTIFICATION}

11. In order that purchasers may be assured that diamond core drill fittings purchased comply with all requirements of this standard, manufacturers may identify products by means of a statement of compliance on labels, invoices, sales literature, etc. 'Where the manufacturer's name, trademark or trade name appears, the following statement is recommended:

This diamond core drill fitting complies with Commercial Standard CS17-47, as issued by the National Bureau of Stanclards of the United States Department of Commerce.

12. When available space on labels is insufficient for the full statement in legible type, an abbreviated statement, as follows, is recommended:

Complies with CS17-47.

13. The following symbol or seal is used in trade literature and advertisements by members of the Diamond Core Drill Manufacturers' Association to indicate equipment manufactured according to this commercial standard.

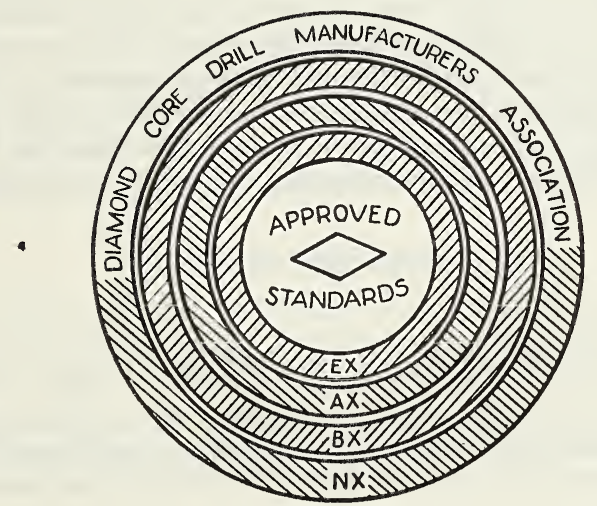

Figure 2.-Seal.

14. Figure 3 illustrates the insignia adopted by the Diamond Core Manufacturers' Association for marking items of diamond core drill equipment conforming to this standard. The significance of the insignia as marked on the equipment is explained in the statement of compliance below, which should accompany each contract and shipment.

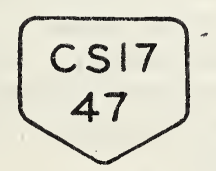

Frgure 3.-Insignia. 


\section{STATEMENT OF COMPLIANCE}

Date-

The diamond core drill equipment marked with the abore insignia has been manufactured by a member of the Dramond CoRE DRILL MANUFACTURERS' ASSOCIATION and complies with COMMERCIAL STANDARD cs17-47, as issued by the NATIONAL BUREAU OF STANDARDS, UNITED STATES DEPARTMENT OF COMMERCE. COMMERCIAI, STANDARD $\operatorname{CS} 17-47$.

Name of manufacturer

\section{EFFECTIVE DATE}

15. The standard becomes effective as a voluntary standard of the trade from July 1, 1947.

\section{STANDING COMMITTEE}

16. The following individuals comprise the membership of the standing committee, which is to review, prior to circulation for acceptance, revisions proposed to keep the standard abreast of progress. Each organization nominated its own representative. Comment concerning the standard and suggestions for revision may be addressed to any member of the committee or to the Division of Trade Standards, National Bureau of Standards, which acts as secretary for the committee.

\section{H. C. Johansen, Chairman}

\section{Manufacturers:}

H. C. Johansen, Joy Manufacturing Co., Sullivan Division, Michigan City, Indiana.

R. D. Long Year, E. J. Longyear Co., 1701 Foshay Tower, Minneapolis, Minn.

B. H. Motr, Mott Core Drilling Co., P. O. Box 2076, Huntington, W. Va.

WM. J. Schank, Sprague \& Henwood, Inc., 221 Olive St., Scranton, Pa.

\section{Users:}

E. L. Derby, JR., Cleveland Cliffs Iron Co., Ishpeming, Mich.

T. B. Sturges, Pennsylvania Drilling Co., 1201 Chartiers Ave., Pittsburgh, Pa.

\section{HISTORY OF PROJECT}

17. On May 27, 1929, at the request of the Diamond Core Drill Manufacturers' Association a general conference of manufacturers, drilling contractors, and general interests was held at Chicago, Ill., to which approximately 1,100 interested organizations had been invited. Pursuant to the action of this conference, the recommended standard was submitted to the trade for written acceptance. Following acceptance by a satisfactory majority, the recommended standard was issued as Commercial Standard CS17-30, being effective for new production on January 1, 1930, and for clearance of existing stocks on July 1, 1930. 


\section{Diamond Core Drill Fittings}

\section{FIRST REVISION}

18. On the recommendation of the Standing Committee, a revised draft was circulated to the industry for written acceptance on March 5,1932 . The revised draft included the new tolerances adopted by the Diamond Core Drill Manufacturers' Association. In general, the changes constitute minor refinements which have developed as a result of experience with the standards and which do not change the important nominal dimensions as set forth in the first edition of the pamphlet. As announced to the trade under date of May 14, 1932, the revised standard was accepted and authorized by the industry for publication as Commercial Standard CS17-32. It was effective for new production and clearance of existing stocks from August 15,1932 .

\section{SECOND REVISION}

19. Pursuant to a request of the Diamond Core Drill Manufacturers' Association dated December 18, 1940, and following approval by the Standing Committee, the second revision was circulated on March 25,1941 , to all concerned for written acceptance. Its chief purpose is to reduce the area of the kerf cut by the two smaller sizes of corebarrel bits, thereby decreasing drill costs and recovering a slightly larger core. The revision provides new, thin-wall core barrels, corebarrel bits and reaming shells designated EX'T and AXT, as well as new flush-joint casings in these two sizes. Following acceptance by a preponderant majority, the second revision was announced and promulgated on May 23, 1941, as Commercial Standard CS17-42.

\section{THIRD REVISION}

20. At the request of the Diamond Core Drill Manufacturers' Association, in view of wartime conditions, the effective date of the second revision was postponed. This automatically continued the 1932 edition in effect. To avoid confusion due to the latest edition not being in effect, and pending completion of developments toward further revision, the Diamond Core Drill Manufacturers' Association recommended that the requirements of the 1932 edition be made available in current commercial standards form. Accordingly, upon endorsement by the Standing Committee, a draft so prepared was circulated on November 21, 1946 for written acceptance. The trade accepted the revised standard which was announced as Commercial Standard CS17-47, effective from July 1, 1947. 



\section{ACCEPTANCE OF COMMERCIAL STANDARD}

If acceptance has not previously been filed, this sheet properly filled in, signed, and returned will provide for the recording of your organization as an acceptor of this commercial standard.

\section{Date}

Division of Trade Standards,

National Bureau of Standards,

Washington $25, \mathrm{D}$. C.

Gentlemen :

We believe that the Commercial Standard CS17-47 constitutes a useful standard of practice, and we individually plan to utilize it as far as practicable as a

$\begin{array}{ll}\text { Manufacturer }^{1} & \square \text { Distributor }^{1} \\ \square \text { Testing Laboratory }^{1} & \square \text { User }^{1}\end{array}$

of diamond core drill fittings. We reserve the right to depart from it as we deem advisable.

We understand, of course, that only those articles which actually comply with the standard in all respects can be identified or labeled as conforming thereto.

Signature of authorized officer

(In ink)

(Kindly typewrite or print the following lines)

Name and title of above officer

Organization $^{2}$

(Fill in exactly a: it should be listed)

Street address

City, zone, and State

1 In the case of related interests, trade associations, trade papers, etc., desiring to record their general support, the words "General support" should be added after the signature.

2 Please see that separate acceptances are filed for all subsidiary companies and affiliates which should be listed separately as acceptors. 


\section{TO THE ACCEPTOR}

The following statements answer the usual questions arising in connection with the acceptance and its significance :

1. Enforcement.-Commercial standards are commodity specifications voluntarily established by mutual consent of those concerned. They present a common basis of understanding between the producer, distributor, and consumer and should not be confused with any plan of governmental regulation or control. The United States Department of Commerce has no regulatory power in the enforcement of their provisions, but since they represent the will of the interested groups as a whole, their provisions through usage soon become established as trade customs, and are made effective through incorporation into sales contracts by means of labels, invoices and the like.

2. The acceptor's responsibility. - The purpose of commercial standards is to establish for specific commodities, nationally recognized grades or consumer criteria and the benefits therefrom will be measurable in direct proportion to their general recognition and actual use. Instances will occur when it may be necessary to deviate from the standard and the signing of an acceptance does not preclude such departures; however, such signature indicates an intention to follow the commercial standard where practicable, in the production, distribution, or consumption of the article in question.

3. The Department's responsibility. - The major function performed by the Department of Commerce in the voluntary establishment of commercial standards on a Nation-wide basis is fourfold: first, to act as an unbiased coordinator to bring all interested parties together for the mutually satisfactory adjustment of trade standards; second, to supply such assistance and advice as past experience with similar programs may suggest; third, to canvass and record the extent of acceptance and adherence to the standard on the part of producers, distributors, and users; and fourth, after acceptance, to publish and promulgate the standard for the information and guidance of buyers and sellers of the commodity.

4. Announcement and promulgation.-When the standard has been endorsed by a satisfactory majority of production or consumption in the absence of active, valid opposition, the success of the project is announced. If, however, in the opinion of the standing committee or the Department of Commerce, the support of any standard is inadequate, the right is reserved to withhold promulgation and publication. 


\section{ACCEPTORS}

21. The organizations listed below have individually accepted this standard for use as far as practicable in the production, distribution, testing, or purchase of diamond core drill fittings. In accepting the standard they reserve the right to depart therefrom as they individually deen advisable. It is expected that articles which actually comply with the requirements of this standard in all respects will be regularly identified or labeled as conforming thereto, and that purchasers will require such specific evidence of conformity.

\section{ASSOCLATIONS}

(General Support)

American Association of Engineers, Chicago, Ill.

Diamond Core Drill Manufacturers Association, New York, N. Y.

Rocky Mountain Coal Mining Institute, The, Denver, Colo.

\section{FIRMS}

Acker Drill Co., Scranton, Pa.

Alabama, Geological Survey of, University, Ala.

Alaska Drilling Co., Juneau, Alaska.

Allegheny River Mining Co., Kittanning, Ia.

Anierican Zinc Co. of Tennessee, Mascot, Tenn.

Anaconda Copper Mining Co., Butte, Mont.

Arkansas Power \& Light Co., Pine Blufi, Ark.

Atkins Co., S. E., Duluth, Minn.

Baltimore, City of, Bureau of Water Supply, Baltimore, Md.

Bath \& Co., Inc., John, Worcester, Mass. (General support).

Beaumont Iron Works Co., Beaumont, Tex. Benedict Coal Corp., st. Charles, Va.

Hethlehem Steel Co., Cornwall Division, Cornwall, Pa.

Bevil Co., Los Angeles, Calif.

Bowdil Co., The, Canton, Ohio.

Bradford Supply Co., Bradford, Pa.

California Division of Highways, Materials \& Research Department, Sacramento, Calif.

California State Bureau of Purchases, Sacramento, Calif.

Canadian Collieries (Dunsmuir), Ltd., Cumberland, B. C., Canada.

Cannon Diamond Drilling Co., Compton, Calif.

Carboloy Co., Inc., Detroit, Mich.

Central Power \& Light Co., Corpus Christi, Tex.

Cliedsey, Wm. R., Champaign, Ill.

Chicago Pneumatic Tool Co., New York, N. Y.

Christensen Diamond Products Co., Salt Lake City, Utah.

Cia. Minera de Penoles S. A., Monterrey, N. L., Mexico.

Cia. Minera, Fundidora y Afinadora, "Monterrey," S. A., Monterrey, N. L., Mexico.

Cities Service Oil Co., Bartlesville, Okla.

Clearfield Bituminous Coal Corp., Indiana, Pa.

Cleveland-Cliffs Iron Co., The, Ishpeming, Mich.

Colburn \& Weiss, Asheville, N. C. (General support).

Columbia Üniversity, School of Mines, New York, N. Y. (General support).

Compania Minera de Penoles, S. A., Avalos Unit, Avalos, Zacatecas, Mexico.

Consolidated Miniug Co., Eureka, Utah.

Denver Machine Shop, Denver, Colo.

Denver Municipal Water Works, Board of Water Commissioners, Denver, Colo.

Diamond Drill Carbon Co., The, New York, X. $\mathbf{Y}$.
Diamond Drill Contracting Co., Inc., Spokane, Wash.

Eagle-Picher Mining \& smelting Co., Tuesoll, Ariz.

Eureka Corp., Ltd., Eureka, Nev.

Failing Supply Co., George E., Enid, Okla.

Foester Co., 1i. W., Ll Paso, Tex.

Gardner-Denver Co., Denver, Colo.

General Industrial Diamond Co., Inc. New York, N. Y.

Grace \& Co., W. R., New York, N. Y.

Hanifell, J. L., New York, N. Y.

Har"za Engineering Co., Chicago, Ill.

Wawley Engineering Corp., Charles B., , D. C.

Healey, Inc., Philip J., New York, N. Y. Ontario, Canada.
Otd., Kirkland Lake,

Homestake Mining Co., Lead, S. Dak. Howard, Needles, Tammen \& Bergendoff,
Kansas City, Mo.

Illinois State Geological Survey, Urbana IIl. (General support).

Illimois Division of Highways, Springfield, III.

Ingersoll Rand Co., New York, N. Y.

Inland Steel Co., Ishpeming, Mich.

Inter-State Iron Co., Pittsburgh, Pa.

Iowa State College, Chemical \& Mining Engineering Department, Ames, Iowa (General support).

Island Creek Coal Ċo, Holden, W. Va.

Irerson Tool Co., Tulsa, Okla.

Jones \& Laughlin Ore Co., Pittsburgh, Pa.

Joy Manufacturing Co., Sullivan Division, Michigan City, Ind.

Kennametal, Inc., Latrobe, Pa.

Kennecott Copper Corp., Nevada Mines Division, Ruth, Ner.

Keplinger \& Wanemmacher. Tulsa, Okla.

Keystome Portland Cement Co., Bath, Pa

Lafayette College, Laston, Pa. (General support).

La Plante, F. R., Ouray, Colo. (General support)

Lehigh Portland Cement Co., Allentown, $\mathrm{Pa}$ Longtin Co., Daniel G., San Francisco, Calif.

Longyear Co., E. J., Minneapolis, Minu.

IrIntyre Porcupine Mines, Ltd., Schumacher, Ontario, Canada.

Metal Carbides Corp., Youngstown, Ohio.

Ietropolitan District Water Supply Commission, Boston, Mass.

Mississippi Lime Co., Alton, Ill.

Missouri School of Mines \& Metallurgy, Rolla, Mo. (General support).

Mott Core Drilling Co., Huntington, W. Va.

National Boring \& Sounding Inc., Quebec, Canada.

National Gypsum Co., N. Holston, Va.

Nebraska, University of, Department of Mechanical Engineering, Lincoln, Nebr. (General support).

New York Coal Sales Co., Columbus, Ohio.

New York Testing Laboratories, Inc., New York. N. Y.

North Dakota, University of, Grand Forks, N. Mak. ((Feneral support). 


\section{Commercial Standard CS17-47}

Northwestern Improvement Co., Roslyn, Wash.

Nova Scotia, Province of, Department of Mines, Halifax, N. S., Canada.

Nutting Co., The H. C., Cincinnati, Ohio.

Odgers, Ira, Crystal Falls, Mich.

Page-Hersey Tubes, Ltd., Toronto, Ontario, Canada.

Pardee \& Curtain Lumber Co., Bergoo, W. Va.

Patzig Testing Laboratories, Des Moines, Iowa.

Pennsylvania Drilling Co., Pittsburgh, Pa.

Philadelphia \& Reading Coal \& Iron Co. Pottsville, $\mathrm{Pa}$.

Picklands Mather \& Co., Duluth, Minn.

Pittsburgh Steel Co., Allenport, Pa.

Processed Diamond Bit \& Tool Co., Inc., San Francisco, Calif.

Pyrites Co., Inc., The, Wilmington, Del. (General support)

Ritter Lumber Co., W. M., Columbus, Ohio.

Roberts, Hugh M., Duluth, Minn. (General support)

Robinson Contracting Co., Ltd., Vancouver, B. C., Canada.

st. Louis, Rocky Mountain \& Pacific Co., Raton, N. Mex.

San Angelo Foundry \& Machine Co., San. Angelo, Tex

Service Steel Co., Los Angeles. Calif.

Silanco Mining \& Refining Co., Itd., Cobalt, Ontario, Canada.

Siscoe Gold Mines, Ltd., Siscoe, Quebec, Canada.

Siscoe Metals, Ltd., O'Brien, Ontario, Canada (General support).
Smit \& Co., Inc., Anton, New York, N. Y.

Smit \& Sons, Inc., J. K., New York, N. I.

Smitl \& Co., Inc., B. F., Boston, Mass.

Smith \& Travers, Co., Ltd., Sudbury, Ontario, Canada.

South Carolina Geological Survey, Columbia, S. C.

Sprague \& Henwood, Inc., Scranton, Pa

Stadacona Mines (1944), Ltd., Rouyn, Quebec, Canarsa.

Thompson \& Lichtner Co., Inc., The, Brookline, Mass.

Twining Laboratories, The, Fresno, Calif. United States Testing Co., Hoboken, N. J. (General support)

Utah, University of, Salt Lake City, Utah. Uvalde Rock Asphalt Co., San Antonio, Tex.

Virginia, University of, Charlottesville, Va.

Washington, State College of, School of Mines, Pullman, Wash. (General support).

West Virginia University, School of Mines, Morgantown, W. Va. (General support).

\section{UNITED STATES GOVERNMENT}

Interior, U. S. Department of the, Geological Survey, Washingion, D. C. (General support)

Interior, U. S. Department of the, Bureau of Mines, Mining Branch, Washington, D. C. ; College Park, Md. ; Bluemont, Va. ; and Juneau, Alaska.

Interior, U. S. Department of the, Bureau of Reclamation, Denver, Colo., and Salt Lake City, Utah.

war Department, Washington, D. C. 


\section{Diamond Core Drill Fittings}

\section{COMMERCIAL STANDARDS}

CS No.

\section{Item}

0-40. Commercial standards and their value to business (third edition).

1-42. Clinical thermometers (third edition).

2-30. Mopsticks.

3-40. stoddard solvent (third edition).

4-29. Staple porcelain (all-clay) plumbing fixtures.

5-46. Pipe nipples; brass, copper steel and wrought-iron (second edition).

6-31. Wrought-iron pipe nipples (second edition). Superseded by CS5-46.

7-29. Standard weight malleable iron or steel screwed unions.

8-41. Gage blanks (third edition).

9-33. Builders' template hardware (second edition).

10-29. Brass pipe nipples. Superseded by CS5-46.

11-41. Moisture regains of cotton yarns (second edition).

12-40. Fuel oils (fifth edition)

13-44. Dress patterns (fourth edition).

14-43. Boys' button-on waists, shirts, junior and sport shirts (made from woven fabrics) (third edition)

15-46. Men's pajama sizes (made from woven fabrics) (third edition).

16-29. Wall paper.

17-47. Diamond core drill fittings (fourth edition).

18-29. Hickory golf shafts.

19-32. Foundry patterns of wood (second edition)

20-47. Staple vitreous china plumbing fixtures (fourth edition).

21-39. Interchangeable ground-glass joints, stopcocks, and stoppers (fourth edition).

22-40. Builders' hardware (nontemplate) (second edition).

23-30. Feldspar.

24-43. Screw threads and tap-drill sizes.

25-30. Special screw threads. Stiperseded by CS24-43.

26-30. Aromatic red cedar closet lining.

27-36. Mirrors (second edition).

28-46. Cotton fabric tents, tarpaulins and covers (second edition).

29-31. Staple seats for water-closet bowls.

30-31. Colors for sanitary ware.

31-38. Wood shingles (fourth edition).

32-31. Cotton cloth for rubber and pyroxylin coating.

33-43. Knit underwear (exclusive of rayon) (second edition).

34-31. Bag, case, and strap leather.

35-47. Hardwood plywood (third edition).

36-33. Fourdrinier wire cloth (second edition ).

37-31. Steel bone plates and screws.

$38-32$. Hospital rubber sheeting.

$39-37$. Wool and part wool blankets (second edition). (Withdrawn as commercial standard, July 14, 1941).

40-32. Surgeons' rubber gloves

41-32. Surgeons' latex gloves.

42-43. Structural fiber insulating board (third edition).

43-32. Grading of sulphonated oils.
CS No.

Item

44-32. Apple wraps.

45-45. Douglas fir plywood (sixth edition).

46-40. Hosiery lengths and sizes (third edition).

47-34. Marking of gold-filled and rolled-gold-plate articles other than watcheases.

48-40. Domestic burners for Pennsylvania anthracite (underfeed type) (second edition).

49-34. Chip board, laminated chip board, and miscellaneous boards for bookbinding purposes.

50-34. Binders board for bookbinding and other purposes.

51-35. Marking articles made of silver in combination with gold.

52-35. Mohair pile fabries (100-percent mohair plain velvet, 100-percent mohair plain frieze, and 50-percent mohair plain frieze).

53-35. Colors and finishes for cast stone.

54-35. Mattresses for hospitals.

55-35. Mattresses for institutions.

56-41. Oak flooring (second edition).

$57-40$. Book cloths, buckrams, and impregnated fabrics for bookbinding purposes except library bindings (second edition).

58-36. Woven elastic fabries for use in overalls (overall elastic webbing).

59-44. Textiles-testing and reporting (fourth edition).

60-36. Hardwood dimension lumber.

61-37. Wood-slat venetian blinds.

62-38. Colors for kitchen accessories.

63-38. Colors for bathroom accessories.

64-37. Walnut veneers

65-43. Methods of analysis and of reporting fiber composition of textile products (second edition).

66-38. Marking of articles made wholly or in part of platinum.

67-38. Marking articles made of karat gold.

68-38. Liquid hypochloride disinfectant, deodorant, and germicide.

69-38. Pine oil disinfectant.

70-41. Phenolic disinfectant (emulsifying type) (second edition) (published with CS71-41).

71-41. Phenolic disinfectant (soluble type) (second edition) (published with CS70-41).

72-38. Household insecticide (liquid spray type).

73-45. Old growth Douglas fir standard stock doors (third edition).

74-39. Solid hardwood wall paneling.

75-42. Automatic mechanical draft oil burners designed for domestic installations (second edition).

76-39. Hardwod interior trim and molding.

77-40. Sanitary cast-iron enameled ware.

78-40. Ground-and-polished lenses for sun glasses (second edition) (published with CS79-40). 
CS No.

79-40.

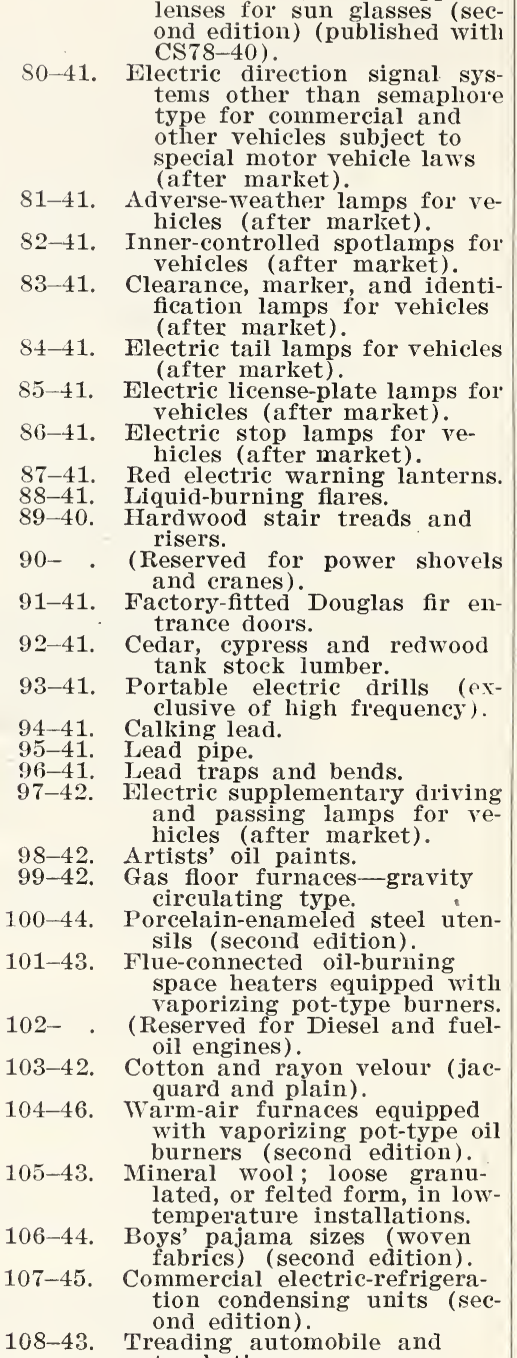

CS No.

109-44. Solid-fuel-burning forced-air furnaces.

110-43. Tire repairs-vulcanized (passenger, truck, and bus tires)

111-43. Earthenware (vitreous-glazed) plumbing fixtures.

112-43. Homogeneous fiber wallboard.

113-44. Oil-burning floor furnaces equipped with vaporizing pot-type burners.

114-43. Hospital sheeting for mattress protection.

115-44. Porcelain-enameled tanks for domestic use.

116-44. Bituminized-fibre drain and sewer pipe.

117-44. Mineral wool; blankets, blocks, insulating cement, and pipe insulation for heated industrial equipment.

118-44. Marking of jewelry and novelties of silver.

(E) 119-45.1 Dial indicators (for linear measurements).

120-46. Standard stock ponderosa pine doors (second edition).

121-45. Women's slip sizes (woven fabries ).

122-45. Western hemlock plywood.

123-45. Grading of diamond powder.

(E) 124-45.1 Master disks.

125-45. Prefabricated homes.

126-45. Tank mounted air compressors.

127-45. Self-contaiued mechanically refrigerated drinking water coolers.

128-45. Men's sport shirt sizes-woven fabrics (other than those marked with regular neckband sizes).

129-47. Matérials for safety wearing apparel (second edition).

130-46. Color materials for art education in schools.

131-46. Industrial mineral wool products, all types-testing and reporting.

132-46. Hardware cloth.

133-46. Woven wire netting.

134-46. Cast aluminum cooking utensils (metal composition).

135-46. Men's shirt sizes (exclusive of work shirts).

136-46. Blankets for hospitals (wool, and wool and cotton).

137-46. Size measurements for men's and boys' shorts (woven fabrics).

138-47. Insect wire screening.

139-47. Work gloves.

140-47. Convectors: testing and rating.

141-47. Sine bars, blocks, plates, and fixtures.

NoTICE.-Those interested in commercial standards with a view toward accepting them as a basis of everyday practice may secure copies of the above standards, while the supply lasts, by addressing the Division of Trade Standards, National Bureau of Standards, Washington 25, D. C.

1 Where "(E)" precedes the CS number, it indicates an emergency commercial standard, drafted under war conditions with a view toward early revision. 